\title{
PERAN TRICHOKOMPOS DAN PUPUK NPK 16-16-16 TERHADAP SERAPAN DAN RESIDU HARA N DAN P, SERTA HASIL JAGUNG KETAN (Zea mays ceratina) \\ Role of Trichocompost and NPK 16-16-16 Fertilizer on N and P Uptake and Residues, and Waxy Corn (Zea mays ceratina) Yield
}

\author{
Yulia Nuraini*, Muzna Aqila \\ Jurusan Tanah, Fakultas Pertanian, Universitas Brawijaya, Jl. Veteran, Malang 65145 \\ *Penulis korespondensi: ynuraini@ub.ac.id
}

\begin{abstract}
Waxy corn still has a low yield potential. The application of NPK 16-16-16 and compost enriched with Trichoderma sp. fungus or Trichocompost can be a solution. This study aimed to determinate the role of Trichocompost and NPK 16-16-16 fertilizer on N and P uptake and residues, and waxy corn yield. Research was conducted using randomized block design consisting of 6 treatments, namely (1) TN0 (Control Without Fertilizer), (2) TN1 (NPK Control), (3) TN2 (Trichocompost $2 \mathrm{t} \mathrm{ha}^{-1}+$ NPK 50\%), (4) TN3 (Trichocompst $2 \mathrm{t} \mathrm{ha}^{-1}+$ NPK 75\%), (5) TN4 (Trichocompost $3 \mathrm{t} \mathrm{ha}^{-1}+$ NPK 50\%) and (6) TN5 (Trichocompost $3 \mathrm{t} \mathrm{ha}^{-1}+\mathrm{NPK} 75 \%$ ). The parameters observed were N and P nutrient uptakes and residues, and waxy corn yield that consisted of fresh weigh of cob with cornhusk, fresh weigh of cob without cornhusk and length of cob. The results showed that Trichocompost and NPK 16-16-16 significantly affected $\mathrm{N}$ and P nutrient uptake, the highest effect was found in TN5, which was $1,57 \mathrm{~g}$ plant $^{-1} \mathrm{~N}$ dan $7,76 \mathrm{~g}$ plant $^{-1} \mathrm{P}$. Residues of $\mathrm{N}$ and $\mathrm{P}$ that left in the soil due to TN5 treatment were also classified as high, which was $0.8 \% \mathrm{~N}$ and $95.2 \mathrm{ppm}$ P. Application of Trichocompost and NPK 16-16-16 fertilizer in TN5 also showed the best yield on waxy corn, which was $202 \mathrm{~g}$ plant $^{-1}$ fresh weigh of cob with cornhusk, 180,7 g plant ${ }^{-1}$ fresh weight of cob without cornhusk and length of cob $18,6 \mathrm{~cm}$.
\end{abstract}

Keywords: NPK 16-16-16 fertilizer, residues, trichocompost, uptake, waxy com

\section{Pendahuluan}

Jagung ditetapkan sebagai komoditas pangan utama, selain beras, kedelai, daging sapi dan gula, selain itu, dalam pembangunan pertanian dan perekonomian Indonesia, jagung digolongkan sebagai komoditas strategis karena memiliki fungsi multiguna (4F), yakni pangan (food), pakan (feed), bahan bakar (fuel) dan bahan baku industri (fiber) (Panikkai et al., 2017). Salah satu jenis jagung lokal yang belum banyak dibudidayakan dan memiliki potensi hasil yang masih rendah yakni 2-3 tha-1 adalah jagung ketan atau waxy com (Zea mays ceratina) (Yasin et al., 2017). Jagung ketan banyak digemari mayarakat karena memiliki rasa gurih, pulen dan penampilan menarik yang berbeda dari jagung pada umumnya. Jagung ketan memiliki kandungan pati dalam bentuk amilopektin hampir 100\%. Amilopektin yang tinggi mempengaruhi rasa dan kadar serat pada jagung sehingga banyak dimanfaatkan oleh penderita diabetes sebagai bahan pangan subtitusi.

Beberapa upaya yang dapat dilakukan untuk meningkatan produksi jagung ketan diantaraya dengan ektensifikasi, yakni perluasan lahan pertanaman jagung sebesar 1 juta ha dengan potensi penambahan hasil hingga 5-6 juta ton (Fitri, 2015) dan intensifikasi berupa pemupukan. Pemupukan dilakukan untuk mengatasi permasalahan umum pada lahan-lahan pertanian di Indonesia, yakni kesuburan tanah akibat rendahnya unsur hara. Penggunaan pupuk 


\section{Jurnal Tanah dan Sumberdaya Lahan Vol 7 No 1 : 93-100, 2020 e-ISSN:2549-9793, doi: 10.21776/ub.jts1.2020.007.1.12}

anorganik, khususnya pupuk NPK masih menjadi pilihan utama petani, karena sifatnya yang fast release dan mudah diserap tanaman, ketergantungan tersebut semakin meningkat dengan kurangnya pemahaman masyarakat akan dampak penggunaan pupuk anorganik berlebihan dan tidak berimbang. Mengatasi permasalahan tersebut, aplikasi pupuk anorganik dan organik secara bersamaan dapat menjadi solusi. Pupuk organik merupakan salah satu faktor penting dalam upaya perbaikan kesuburan tanah (Muznamar, 2003).

Pengkayaan pupuk organik secara mikrobiologis mulai banyak dikembangkan dan digunakan karena memiliki banyak keuntungan, diantaranya mempercepat penguraian, ramah lingkungan, tidak mengganggu organisme lain terutama yang berada di dalam tanah dan tidak meninggalkan residu di dalam tanaman maupun tanah (Amin et al., 2015). Teknologi pemberian kompos yang diperkaya jamur Trichoderma sp. atau Trichokompos terbukti dapat meningkatkan kandungan hara tanah, pertumbuhan dan produksi jagung pada lahan kering (Afitin dan Darmanti, 2009), selain itu, penggunaan kombinasi $3 / 4$ dosis pupuk NPK dan pupuk organik yang diperkaya mikroba fungsional dapat memberikan hasil jagung yang sama baiknya dengan takaran NPK standar (Erselina et al., 2017). Berdasarkan uraian tersebut, maka penelitian dilakukan untuk mengetahui peran pemberian Trichokompos dan NPK 16-16-16 untuk menunjang pertumbuhan dan hasil jagung ketan, serta serapan dan residu hara Nitrogen (N) dan Fosfor (P) dalam tanah.

\section{Metode Penelitian}

Penelitian dilaksanakan pada Maret hingga Juni 2019 di screenhouse Lahan Percobaan Jatimulyo, kemudian analisis tanah dan tanaman dilakukan di Laboratorium Kimia Tanah, Jurusan Tanah, Fakultas Pertanian, Universitas Brawijaya. Bahan yang digunakan meliputi tanah Inceptisol yang diambil dari lahan percobaan, benih tanaman jagung ketan Arumba PT. Agri Makmur Pertiwi, pupuk NPK 16-16-16 ‘Cap Tawon', pupuk Urea dan pupuk SP-36 sebagai pupuk tambahan dan Trichokompos yang diproduksi oleh Balai Pengkajian Teknologi Pertanian (BPTP) Jawa Timur. Penelitian dilaksanakan dengan Rancangan Acak Kelompok (RAK) yang terdiri dari 6 perlakuan dan 3 kali ulangan, yakni kontrol tanpa pupuk (TN0), kontrol NPK 16-16-16 (TN1) dan takaran kombinasi NPK 16-16-16 dengan Trichokompos, meliputi TN2 (Trichokompos $2 \mathrm{t} \mathrm{ha}^{-1}$ dan NPK 50\%), TN3 (Trichokompos $2 \mathrm{t} \mathrm{ha}^{-1}$ dan NPK 75\%), TN4 (Trichokompos $3 \mathrm{t} \mathrm{ha}^{-1}$ dan NPK 50\%), dan TN5 (Trichokompos $3 \mathrm{t} \mathrm{ha}^{-1}$ dan NPK 75\%). Parameter yang diamati meliputi serapan hara $\mathrm{N}$ dan P saat 30 HST, pH, C-Organik, Residu NTotal dan P-Tersedia saat 60 HST, serta hasil jagung ketan, meliputi bobot segar tongkol berkelobot dan tanpa kelobot, serta panjang tongkol. Data yang diperoleh kemudian dianalisis dengan Analysis of $V$ ariance (ANOVA) Uji-F taraf 5\% untuk mengetahui pengaruh perlakuan yang diteliti. Apabila didapatkan pengaruh nyata, maka data yang diperoleh diuji kembali dengan uji lanjut Duncan's Multiple Range Test (DMRT) taraf 5\%.

\section{Hasil dan Pembahasan}

\section{Serapan N}

Salah satu indikator tercukupinya unsur hara dalam tanaman adalah dengan mengukur serapan haranya. Serapan hara merupakan hasil perkalian antara kadar hara tanaman dengan berat kering tanaman. Serapan hara menunjukkan banyaknya hara dalam tanah dan kemampuan tanaman untuk menyerap unsur hara. Pengukuran serapan hara pada penelitian ini dilakukan pada 30 HST yang merupakan fase vegetatif maksimum. Vegetatif maksimum adalah masa saat jagung ketan telah mencapai tinggi makimum dan mulai menyebarkan serbuk sari (pollen). Hasil analisis ragam pemberian Trichokompos dan pupuk NPK 16-16-16 dengan berbagai tingkatan dosis berpengaruh nyata pada serapan $\mathrm{N}$, sedangkan hasil uji lanjut menunjukkan perlakuan TN5 berbeda nyata dibandingkan perlakuan lainnya (Tabel 1). Meningkatnya serapan N pada jagung ketan sejalan dengan semakin tingginya dosis Trichokompos dan pupuk NPK 16-16-16, hal ini menunjukkan bahwa tanah pada perlakuan dengan aplikasi perlakuan tertinggi yakni TN5 mampu menyediakan unsur hara yang paling optimal untuk pertumbuhan tanaman.

Pupuk NPK 16-16-16 yang diberikan pada jagung ketan lebih cepat tersedia bagi tanaman. Unsur hara dilepaskan oleh pupuk NPK melalui 


\section{Jurnal Tanah dan Sumberdaya Lahan Vol 7 No 1 : 93-100, 2020 e-ISSN:2549-9793, doi: 10.21776/ub.jts1.2020.007.1.12}

hidrolisis pupuk dengan air dalam tanah. Reaksi hidrolisis akan menyebabkan ionisasi pada masing-masing unsur hara pada pupuk sehingga unsur hara tersebut dapat langsung dimanfaatkan oleh tanaman untuk pertumbuhannya, sedangkan Trichokompos yang diaplikasikan bersamaan dengan pupuk NPK dapat memberikan tambahan unsur hara yang dibutuhkan oleh tanaman, baik unsur hara makro maupun mikro. Trichokompos juga berperan dalam menurunkan kehilangan unsur hara, karena gugus karboksil (-COOH) dan fenolik ($\mathrm{OH})$ milik Trichokompos yang bermuatan negatif mampu mengikat unsur hara yang dilepaskan oleh pupuk NPK. Pemberian Trichokompos yang merupakan pupuk organik juga dapat memperbaiki struktur tanah, meningkatkan kemampuan tanah dalam mengikat air dan menambah ketersediaan unsur N, P dan K (Siregar dan Hartatik, 2010).

\section{Serapan $\boldsymbol{P}$}

Status hara dalam tanah dapat diketahui dari kandungan unsur hara pada jaringan tanaman yang tumbuh diatasnya. Hal tersebut dikarenakan kandungan unsur hara dalam tanah berkolerasi dengan kandungan hara pada jaringan tanaman (Suharto et al., 2018). Hasil analisis ragam menunjukkan bahwa serapan $\mathrm{P}$ tanaman jagung ketan pada berbagai tingkatan dosis Trichokompos dan pupuk NPK 16-16-16 berpengaruh nyata. Serapan P pada perlakuan TN5 berbeda nyata dengan perlakuan TN0, TN1 dan TN2. Aplikasi perlakuan TN5 memberikan hasil serapan P paling tinggi pada jagung ketan saat vegetatif maksimum, yakni 7,76 g tan-1, meningkat 291,9\% dari serapan P pada perlakuan TN0 dan meningkat $230,2 \%$ dari serapan $P$ pada perlakuan TN1 yang secara berurutan TN0 dan TN1 memiliki serapan P 1,98 $\mathrm{g} \tan ^{-1}$ dan 2,35 g $\tan ^{-1}$ (Tabel 1).

Tabel 1. Pengaruh aplikasi trichokompos dan pupuk NPK 16-16-16 terhadap serapan hara N dan P jagung ketan pada 30 HST

\begin{tabular}{|c|c|c|c|c|c|c|}
\hline \multirow[t]{2}{*}{ Kode } & \multirow{2}{*}{$\begin{array}{c}\text { Serapan N } \\
\left(g^{2} \tan ^{-1}\right)\end{array}$} & \multicolumn{2}{|c|}{$\%$ Peningkatan Terhadap } & \multirow{2}{*}{$\begin{array}{c}\text { Serapan P } \\
\mathrm{g} \tan ^{-1}\end{array}$} & \multicolumn{2}{|c|}{$\%$ Peningkatan Terhadap } \\
\hline & & TN0 & TN1 & & TN0 & TN1 \\
\hline TN0 & $0,36 \mathrm{a}$ & 0 & - & $1,98 \mathrm{a}$ & 0 & - \\
\hline TN1 & $0,42 \mathrm{a}$ & 16,6 & 0 & $2,35 \mathrm{a}$ & 18,7 & 0 \\
\hline TN2 & $0,78 \mathrm{a}$ & 116,6 & 85,7 & $3,30 \mathrm{a}$ & 66,6 & 40,4 \\
\hline TN3 & $0,80 \mathrm{ab}$ & 122,2 & 90,5 & $4,34 \mathrm{ab}$ & 119,2 & 84,7 \\
\hline TN4 & $0,96 \mathrm{ab}$ & 166,6 & 128,6 & $5,25 \mathrm{ab}$ & 165,1 & 123,4 \\
\hline TN5 & $1,57 \mathrm{~b}$ & 336,1 & 273,8 & $7,76 \mathrm{~b}$ & 291,9 & 230,2 \\
\hline
\end{tabular}

Keterangan: Angka yang didampingi huruf yang sama pada kolom yang sama menunjukkan hasil yang tidak berbeda nyata pada uji lanjut DMRT taraf 5\%; HST: Hari Setelah Tanam; dosis NPK 100\% (219 kg ha-1), NPK $50 \%\left(109 \mathrm{~kg} \mathrm{ha}^{-1}\right)$ dan NPK 75\% (164 $\left.\mathrm{kg} \mathrm{ha}^{-1}\right)$.

Aplikasi Trichokompos $3 \mathrm{t} \mathrm{ha}^{-1}$ dan pupuk NPK 75\% pada TN5 mampu menyediakan unsur hara $\mathrm{P}$ dalam tanah sehingga serapannya pun menjadi optimum, semakin tinggi kandungan unsur hara dalam tanah akan berbanding lurus dengan kadar hara pada jaringan tanaman yang tumbuh diatasnya karena tanaman akan lebih mudah menyerap unsur hara dan memenuhi kebutuhannya apabila ketersediaannya dalam tanah juga tinggi, begitupun sebaliknya. Kasno dan Tia (2013) menyatakan bahwa pemupukan NPK mampu meningkatkan serapan $\mathrm{P}$ pada jagung dibandingkan dengan tanah yang tidak diberi pupuk NPK, selain itu, pemberian bahan organik berupa Trichokompos juga dapat meningkatkan P. Bentuk organik pada Trichokompos diubah ke bentuk anorganik dengan bantuan mikroba selama proses dekomposisi serta menghasilkan asam organik yang berperan dalam pelepasan $\mathrm{P}$ yang terfiksasi menjadi P-Tersedia yang dapat diserap oleh tanaman.

\section{Residu Hara}

\section{Kemasaman aktif ( $p H)$}

Nilai pH adalah ukuran kemasaman atau konsentrasi $\mathrm{H}^{+}$dalam larutan tanah. Nilai $\mathrm{pH}$ mempengaruhi ketersediaan unsur hara di dalam 


\section{Jurnal Tanah dan Sumberdaya Lahan Vol 7 No 1 : 93-100, 2020 e-ISSN:2549-9793, doi: 10.21776/ub.jts1.2020.007.1.12}

tanah dan menentukan mudah tidaknya unsur hara tersebut untuk diserap tanaman. Hasil analisis ragam pemberian Trichokompos dan pupuk NPK 16-16-16 dengan berbagai tingkatan dosis berpengaruh nyata terhadap $\mathrm{pH}$ tanah setelah panen, sedangkan hasil uji lanjut menunjukkan bahwa perlakuan TN4 dan TN5 berbeda nyata dengan perlakuan TN0 dan TN1 (Tabel 2). Nilai pH tanah setelah panen (60 HST) cenderung meningkat daripada kontrol seiring dengan penambahan dosis Trichokompos dan pupuk NPK 16-16-16. Nilai pH tertinggi terdapat pada perlakuan TN5 dan nilai terendah pada perlakuan TN1. Hasil tersebut menunjukkan bahwa TN4 dan TN5 yang merupakan perimbangan pupuk organik (Trichokompos) dan pupuk anorganik (pupuk NPK 16-16-16) merupakan perlakuan terbaik dibandingkan perlakuan lainnya. Meningkatnya $\mathrm{pH}$ tanah diduga akibat aplikasi bahan organik berupa Trichokompos. Proses perombakan Trichokompos dalam tanah akan menghasilkan asam-asam organik yang dapat mengikat kation- kation asam, seperti $\mathrm{H}^{+}$melalui gugus karboksil yang bermuatan negatif, sehingga $\mathrm{pH}$ tanah meningkat. Sedangkan, aplikasi pupuk NPK sendirian justru akan menurunkan $\mathrm{pH}$ tanah, terlihat dari $\mathrm{pH}$ tanah perlakuan TN1 yang justru menurun dibandingkan $\mathrm{pH}$ TN0, hal ini disebabkan karena pemberian pupuk $\mathrm{N}$ dalam bentuk $\mathrm{NH}_{4}{ }^{+}$dan $\mathrm{NO}_{3}{ }^{-}$dapat menurunkan $\mathrm{pH}$, namun penurunan $\mathrm{pH}$ semakin berkurang dengan meningkatnya dosis Trichokompos yang diberikan. Sulaeman et al. (2017) juga menyebutkan bahwa penggunaan bahan organik dapat meningkatkan $\mathrm{pH}$ tanah dan menurunkan kejenuhan $\mathrm{Al}$ di dalam tanah.

\section{C-organik}

Hasil analisis ragam pemberian Trichokompos dan pupuk NPK 16-16-16 dengan berbagai tingkatan dosis berpengaruh nyata pada nilai residu C-Organik saat 60 HST (setelah panen). Nilai C-Organik tertinggi terdapat pada perlakuan TN4 dan TN5, yakni 4,8\% dan 4,9\%, berbeda nyata dengan perlakuan TN0 (Tabel 2).

Tabel 2. Pengaruh aplikasi trichokompos dan pupuk NPK 16-16-16 terhadap pH dan residu Corganik pada 60 HST

\begin{tabular}{ccccc}
\hline Kode & pH & C-Organik (\%) & \multicolumn{2}{c}{ \% Peningkatan Terhadap } \\
\cline { 3 - 4 } & & & 0 & TN0 \\
\hline TN0 & $6,5 \mathrm{a}$ & $2,6 \mathrm{a}$ & 26,9 & - \\
TN1 & $6.4 \mathrm{a}$ & $3,3 \mathrm{ab}$ & 42,3 & 0 \\
TN2 & $6,9 \mathrm{~b}$ & $3,7 \mathrm{bc}$ & 50,0 & 12,1 \\
TN3 & $6,8 \mathrm{~b}$ & $3,9 \mathrm{c}$ & 84,6 & 18,2 \\
TN4 & $7,1 \mathrm{c}$ & $4,8 \mathrm{~d}$ & 85,4 & 45,4 \\
TN5 & $7,2 \mathrm{c}$ & $4,9 \mathrm{~d}$ & 88,4 & 48,5 \\
\hline
\end{tabular}

Keterangan: Angka yang didampingi huruf yang sama pada kolom yang sama menunjukkan hasil yang tidak berbeda nyata pada uji lanjut DMRT taraf 5\%; HST: Hari Setelah Tanam; dosis NPK 100\% (219 kg ha-1), NPK 50\% (109 $\left.\mathrm{kg} \mathrm{ha}^{-1}\right)$ dan NPK 75\% (164 kg ha-1).

Hasil pengukuran C-Organik tersebut menunjukkan bahwa semakin tinggi dosis Trichokompos yang diaplikasikan maka semakin tinggi pula nilai C-Organik yang terkandung dalam tanah, sedangkan pupuk NPK tidak mempengaruhi jumlah C-Organik. Hal ini dapat dilihat dari rendahnya C-Organik pada perlakuan TN0 dan TN1, sedangkan C-Organik pada perlakuan TN2, TN3, TN4 dan TN5 yang merupakan perimbangan Trichokompos dan pupuk NPK terjadi peningkatan. Kandungan C-Organik pada perlakuan TN4 dan TN5 dapat dikategorikan tinggi karena berada pada rentang C-Organik 3-5\% (Balittanah, 2009).

Aplikasi Trichokompos ke dalam tanah dapat menyebabkan peningkatan nilai C-Organik. Afandi et al. (2015) menyatakan bahwa peningkatan C-Organik akan mempengaruhi sifat tanah secara kimia, fisika maupun biologi. Pemberian bahan organik dapat meningkatkan pertumbuhan dan aktifitas mikroba tanah, karena bahan organik menjadi sumber energi dan bahan makanan bagi mikroba tersebut (Ansori, 2011). C-Organik sebagai sumber makanan organisme yang semakin tinggi 


\section{Jurnal Tanah dan Sumberdaya Lahan Vol 7 No 1 : 93-100, 2020 e-ISSN:2549-9793, doi: 10.21776/ub.jts1.2020.007.1.12}

akan memacu kegiatan mikroorganisme sehingga meningkatkan proses dekomposisi dan reaksireaksi kimia yang memerlukan bantuan mikroorganisme, seperti pelarutan fosfor $(\mathrm{P})$ dan fiksasi nitrogen $(\mathrm{N})$.

\section{$N$-total}

Penambahan Trichokompos dan pupuk NPK 16-16-16 pada berbagai tingkatan dosis memberikan pengaruh nyata pada residu $\mathrm{N}$ Total dalam tanah saat 60 HST (setelah panen). Perlakuan TN4 dan TN5 berbeda nyata dengan TN0 dan TN1 (Tabel 3). Peningkatan N-Total pada tiap perlakuan sejalandengan penambahan dosis Trichokompos dan pupuk NPK 16-16-16. Perlakuan TN1 hanya meningkatkan residu NTotal 33,3\% dibandingkan TN0, sedangkan perlakuan TN4 dan TN5 mampu meningkatkan residu N-Total sebesar 75\% dan 100\% dibandingkan TN1, artinya penambahan Trichokompos mampu meningkatkan residu N-Total pada tanah lebih baik 2 kali lipat dibandingkan penambahan pupuk NPK sendirian. Residu N-Total yang tinggi mengindikasikan Trichokompos sebagai bahan organik dapat menyumbangkan $\mathrm{N}$ dalam tanah karena telah terjadi pelepasan hara dari proses dekomposisi dan mineralisasi bahan organik tersebut, selain itu unsur N dari pupuk NPK yang diaplikasikan bersamaan dengan Trichokompos tidak mudah hilang akibat menguap dan tercuci karena adanya ikatan antara gugus karboksil $(-\mathrm{COOH})$ dan fenolik $(-\mathrm{OH})$ yang bermuatan negatif dari bahan organik dengan $\mathrm{NH}_{4}{ }^{+}$dari pupuk NPK terhidrolisis yang bermuatan positif.

\section{P-tersedia}

Aplikasi Trichokompos dan pupuk NPK 16-1616 pada berbagai tingkatan dosis memberikan pengaruh nyata pada residu P-Tersedia saat 60 HST (setelah panen). Perlakuan TN4 dan TN5 menunjukkan hasil yang berbeda nyata terhadap perlakuan TN0 (Tabel 3). Meningkatnya residu P-Tersedia pada akhir pertanaman disebabkan oleh pelepasan $\mathrm{P}$ dari bahan organik, serta adanya pupuk yang tertinggal didalam tanah dari musim tanam sebelumnya, mengingat tanah yang digunakan pada budidaya jagung ketan ini merupakan tanah bekas pertanaman jagung dan kacang tanah pada musim tanam sebelumnya. Tidak semua P yang ditambahkan dalam bentuk pupuk akan tetap tersedia bagi tanaman pertama, residunya akan tetap tersedia dalam tanah untuk diserap tanaman berikutnya, hal ini disebabkan oleh mobilitas $\mathrm{P}$ yang rendah dalam tanah (Handayanto et al., 2017). Tabel 3 menunjukkan bahwa kandungan P-Tersedia terus meningkat seiring dengan penambahan Trichokompos dan pupuk NPK.

Tabel 3. Pengaruh aplikasi trichokompos dan pupuk NPK 16-16-16 terhadap residu N-total dan Ptersedia pada 60 HST

\begin{tabular}{|c|c|c|c|c|c|c|}
\hline \multirow[t]{2}{*}{ Kode } & \multirow{2}{*}{$\begin{array}{c}\text { N-Total } \\
(\%)\end{array}$} & \multicolumn{2}{|c|}{$\%$ Peningkatan Terhadap } & \multirow{2}{*}{$\begin{array}{c}\text { P-Tersedia } \\
(\mathrm{ppm})\end{array}$} & \multicolumn{2}{|c|}{$\%$ Peningkatan Terhadap } \\
\hline & & TN0 & TN1 & & TNO & TN1 \\
\hline TNO & $0,3 \mathrm{a}$ & 0 & - & $1,98 \mathrm{a}$ & 0 & - \\
\hline TN1 & $0,4 \mathrm{a}$ & 33,3 & 0 & $2,35 \mathrm{a}$ & 18,7 & 0 \\
\hline TN2 & $0,5 \mathrm{~b}$ & 66,6 & 25 & $3,30 \mathrm{a}$ & 66,6 & 40,4 \\
\hline TN3 & $0,5 \mathrm{~b}$ & 66,6 & 25 & $4,34 \mathrm{ab}$ & 119,2 & 84,7 \\
\hline TN4 & $0,7 \mathrm{c}$ & 133,3 & 75 & $5,25 \mathrm{ab}$ & 165,1 & 123,4 \\
\hline TN5 & $0,8 \mathrm{c}$ & 166,6 & 100 & $7,76 \mathrm{~b}$ & 291,9 & 230,2 \\
\hline
\end{tabular}

Keterangan: Angka yang didampingi huruf yang sama pada kolom yang sama menunjukkan hasil yang tidak berbeda nyata pada uji lanjut DMRT taraf 5\%; HST: Hari Setelah Tanam; dosis NPK 100\% (219 kg ha-1), NPK $50 \%\left(109 \mathrm{~kg} \mathrm{ha}^{-1}\right)$ dan NPK 75\% (164 kg ha-1).

Pemberian bahan organik bersama-sama dengan pupuk anorganik pada perlakuan TN4 dan TN5 lebih baik dibandingkan pemberian pupuk anorganik secara sendirian. Pupuk NPK dapat menyediakan P dalam waktu yang singkat karena sifatnya yang fast release, sedangkan pengaruh
Trichokompos pada ketersediaan P dapat secara langsung melalui mineralisasi dan secara tidak langsung dengan membantu pelepasan $\mathrm{P}$ yang terfiksasi. Meningkatnya residu P-Tersedia menjadi lebih tinggijuga disebabkan ketersediaan P dalam tanah yang bersifat sangat stabil (imobile), 


\section{Jurnal Tanah dan Sumberdaya Lahan Vol 7 No 1 : 93-100, 2020 e-ISSN:2549-9793, doi: 10.21776/ub.jts1.2020.007.1.12}

sehingga kehilangan hara oleh pencucian relatif jarang terjadi (Suharto et al., 2018).

\section{Hasil jagung ketan}

Bobot segar tongkol

Hasil analisis ragam pemberian Trichokompos dan Pupuk NPK 16-16-16 dengan berbagai tingkatan dosis pada jagung ketan memberikan pengaruh nyata pada bobot segar tongkol berkelobot dan bobot segar tongkol tanpa kelobot. Perlakuan TN3, TN4 dan TN5 menunjukkan hasil yang berbeda nyata terhadap perlakuan TN0, TN1 dan TN2 (Tabel 4). Aplikasi Trichokompos dan pupuk NPK 16-16-16 dengan dosis yang meningkat memberikan peningkatan terhadap bobot segar tongkol berkelobot dan bobot segar tongkol tanpa kelobot dibandingkan kontrol.

Tabel 4. Pengaruh aplikasi trichokompos dan pupuk NPK 16-16-16 terhadap bobot segar tongkol berkelobot dan tanpa kelobot.

\begin{tabular}{|c|c|c|c|c|c|c|}
\hline \multirow[t]{3}{*}{ Kode } & \multirow{3}{*}{$\begin{array}{c}\text { Bobot Segar } \\
\text { Tongkol }+ \text { Kelobot } \\
\left(\mathrm{g}^{-1 a n}{ }^{-1}\right)\end{array}$} & \multirow{3}{*}{$\begin{array}{c}\text { Bobot Segar Tongkol } \\
\text { Tanpa Kelobot } \\
\left(\mathrm{g} \mathrm{tan}^{-1}\right) \\
\end{array}$} & \multicolumn{4}{|c|}{$\%$ Peningkatan Terhadap } \\
\hline & & & \multicolumn{2}{|c|}{ TN0 } & \multicolumn{2}{|c|}{ TN1 } \\
\hline & & & $*$ & $* *$ & $*$ & $* *$ \\
\hline TN0 & $106,4 \mathrm{a}$ & $92,4 \mathrm{a}$ & 0 & 0 & - & - \\
\hline TN1 & $125,9 \mathrm{a}$ & 97,9 a & 18,3 & 5,9 & 0 & 0 \\
\hline TN2 & $130,5 \mathrm{a}$ & $117,3 \mathrm{a}$ & 22,6 & 26,9 & 3,6 & 19,8 \\
\hline TN3 & $180,6 \mathrm{~b}$ & $157,6 \mathrm{~b}$ & 69,7 & 70,5 & 43,4 & 61,0 \\
\hline TN4 & $182,4 \mathrm{~b}$ & $171,1 \mathrm{~b}$ & 71,4 & 85,2 & 44,9 & 74,8 \\
\hline TN5 & $202,5 \mathrm{~b}$ & $180,7 \mathrm{~b}$ & 90,3 & 95,5 & 60,8 & 84,6 \\
\hline
\end{tabular}

Keterangan: Angka yang didampingi huruf yang sama pada kolom yang sama menunjukkan hasil yang tidak berbeda nyata pada uji lanjut DMRT taraf 5\%; HST: Hari Setelah Tanam; dosis NPK 100\% (219 kg ha-1), NPK $50 \%\left(109 \mathrm{~kg} \mathrm{ha}^{-1}\right)$ dan NPK 75\% (164 kg ha-1).

Pirngandi et al. (2005) menyatakan bahwa pupuk NPK merupakan pupuk majemuk dengan kandungan unsur hara yang lengkap dan seimbang sehingga mampu dimanfaatkan oleh tanaman secara maksimal, sedangkan Trichokompos merupakan bahan organik yang mengandung unsur hara utama $\mathrm{N}, \mathrm{P}, \mathrm{K}$ dan $\mathrm{Mg}$. Kedua pupuk tersebut dapat saling melengkapi dan menyebabkan peningkatan pada bobot segar tongkol. Berdasarkan data tersebut, meskipun bobot segar tongkol tertinggi didapatkan pada perlakuan TN5, namun perlakuan TN3 diketahui telah mampu secara nyata meningkatkan bobot segar tongkol, sehingga dapat dikatakan perlakuan TN3 paling menguntungkan dalam kegiatan budidaya jagung ketan karena hanya membutuhkan Trichokompos $2 \mathrm{t} \mathrm{ha}^{-1}$ dan dosis pupuk NPK 75\%.

Panjang tongkol

Hasil analisis ragam menunjukkan bahwa berbagai tingkatan dosis Trichokompos dan pupuk NPK 16-16-16 memberikan pengaruh nyata pada panjang tongkol jagung ketan. Perlakuan TN4 dan TN5 menunjukkan hasil yang berbeda nyata dengan perlakuan TN0 (Tabel 5). Meningkatnya panjang tongkol pada hasil panen jagung ketan disebabkan oleh kondisi lingkungan yang optimal dan hara yang tercukupi dalam tanah. Terpenuhinya kebutuhan akan unsur hara, cahaya dan air akan menstimulasi tanaman untuk berfotosintesis dengan baik.

Tabel 5. Pengaruh aplikasi trichokompos dan pupuk NPK 16-16-16 terhadap panjang tongkol

\begin{tabular}{|c|c|c|c|}
\hline \multirow[t]{2}{*}{ Kode } & \multirow[t]{2}{*}{$\begin{array}{c}\text { Panjang } \\
\text { Tongkol }(\mathrm{cm})\end{array}$} & \multicolumn{2}{|c|}{$\begin{array}{l}\text { \% Peningkatan } \\
\text { Terhadap }\end{array}$} \\
\hline & & TN0 & TN1 \\
\hline TN0 & $13,2 \mathrm{a}$ & 0 & - \\
\hline TN1 & $14,8 \mathrm{ab}$ & 12,1 & 0 \\
\hline TN2 & $14,9 \mathrm{~b}$ & 12,9 & 0,7 \\
\hline TN3 & $17,6 \mathrm{~cd}$ & 33,3 & 18,9 \\
\hline TN4 & $18,1 \mathrm{~d}$ & 37,1 & 22,3 \\
\hline TN5 & $18,6 \mathrm{~d}$ & 40,9 & 25,7 \\
\hline
\end{tabular}

Keterangan: Angka yang didampingi huruf yang sama pada kolom yang sama menunjukkan hasil yang tidak berbeda nyata pada uji lanjut DMRT taraf 5\%; HST: Hari Setelah Tanam; dosis NPK 100\% (219 kg ha-1), NPK 50\% (109 kg ha-1) dan NPK 75\% (164 kg ha-1). 


\section{Jurnal Tanah dan Sumberdaya Lahan Vol 7 No 1 : 93-100, 2020 e-ISSN:2549-9793, doi: 10.21776/ub.jts1.2020.007.1.12}

Fotosintat yang dihasilkan lalu ditransfer dan disimpan dalam tongkol dan biji. Perlakuan TN4 dan TN5 yang diaplikasikan pupuk NPK 16-1616 dengan dosis $50 \%$ dan $75 \%$ telah mampu menyediakan unsur hara secara lengkap dan cepat (fast release), sedangkan Trichokompos $3 \mathrm{t}$ ha $^{-1}$ mampu membentuk kondisi tanah yang baik dan menyediakan hara dalam jangka waktu yang panjang (slow release). Trichokompos akan memberikan pengaruh langsung dan tidak langsung pada kesuburan tanah. Pengaruh langsung disebabkan oleh pelepasan unsur hara melalui mineralisasi, sedangkan pengaruh tidak langsung yakni melalui akumulasi bahan organik tanah, yang pada gilirannya juga akan meningkatkan penyediaan unsur hara tanaman (Kurnilawati et al., 2013).

\section{Kesimpulan}

1. Penambahan Trichokompos dan pupuk NPK 16-16-16 memberikan pengaruh nyata pada serapan $\mathrm{N}$ dan $\mathrm{P}$ dibandingkan perlakuan pupuk NPK saja. Perlakuan TN5 berpotensi meningkatkan dan memiliki nilai serapan paling tinggi yakni $1,57 \mathrm{~g} \mathrm{tan}^{-1} \mathrm{~N}$ dan 7,76 $\mathrm{g}_{\tan ^{-1}} \mathrm{P}$.

2. Trichokompos dan pupuk NPK 16-16-16 yang diaplikasikan pada budidaya jagung ketan dapat meningkatkan dan memberikan pengaruh nyata pada residu N-Total dan PTersedia dalam tanah. Perlakuan TN4 dan TN5 meningkatkan N-Total menjadi 0,7\% dan $0,8 \%$, serta P-Tersedia 90,9 ppm dan 95,2 ppm.

3. Aplikasi Trichokompos dan pupuk NPK 1616-16 dengan dosis yang meningkat diikuti dengan meningkatnya komponen hasil jagung ketan, meliputi bobot segar tongkol berkelobot, bobot segar tongkol tanpa kelobot dan panjang tongkol. Perlakuan TN5 menghasilkan komponen hasil paling baik dibandingkan perlakuan lainnya, yakni bobot segar tongkol berkelobot 202,5 $\mathrm{g} \mathrm{tan}^{-1}$, bobot segar tongkol tanpa kelobot 180,7 $\mathrm{g} \tan ^{-1}$ dan panjang tongkol 18,6 cm.

\section{Daftar Pustaka}

Afandi, F.N., Siswanto, B. dan Nuraini, Y. 2015. Pengaruh pemberian berbagai jenis bahan organik terhadap sifat kimia tanah pada pertumbuhan dan produksi ubi jalar di Entisol Ngrangkah Pawon, Kediri. Jurnal Tanah dan Sumberdaya Lahan 2 (2): 237-244.

Afitin, R. and Darmanti, S. 2009. Pengaruh dosis kompos dengan stimulator trichoderma terhadap pertumbuhan dan produksi tanaman jagung (Zea mays L.) varietas Pioner -11 pada lahan kering. BIOMA. 11 (2): 69-75.

Amin, F., Adiwirman, dan Yosefa, S. 2015. Studi waktu aplikasi pupuk kompos leguminosa dengan bioaktifator Trichoderma sp. terhadap pertumbuhan dan produksi tanaman cabai merah (Capcisum annum L.). Jurnal Jom Faperta 2(1): 1-15.

Ansori, T. 2011. Pengaruh Bahan Organik pada Sifat Biologi Tanah. Diakses di http://www.lestarimandiri.org/id/pupukorganik /156bahan-organik.html pada 10 Juli 2019.

Balittanah. 2009. Analisis Kimia Tanah, Tanaman, Air dan Pupuk. Bogor: Balai Penelitian Tanah. p 209211.

erselina, i., respatie, d.w., dan rogomulyo, r. 2017. pengaruh takaran kombinasi pupuk npk dan pupuk organik alami diperkaya mikroba fungsional terhadap pertumbuhan dan hasil jagung. Jurnal Vegetalika 6 (4): 28-40.

Fitri, S. 2015. Kementan: Masalah Jagung Kompleks. Diakses di: https://www.repub-lika.co.id pada 26 November 2018.

Handayanto, E., Muddarisna, N. dan Fiqri, A. 2017. Pengelolaan Kesuburan Tanah. Malang: UB Press. p 44-46.

Kasno, A. dan T. Rostaman. 2013. Serapan hara dan peningkatan produksi jagung dengan aplikasi NPK majemuk. Jurnal Penelitian Tanaman Pangan 32 (2): 179-187.

Kurnilawati, S. dan Syakur. 2013. Phosfat tersedia, serapannya serta pertumbuhan jagung (Zea mays L.) akibat amelioran dan mikoriza pada Andisol. Jurnal Manajemen Sumberdaya Lahan 3 (2): 231239.

Muznamar, E.I. 2003. Pupuk Organik: Cair Dan Padat, Pembuatan, Aplikasi. Jakarta: Penebar Swadaya. p 23-24.

Panikkai, S., Nurmalina, R., Mulatsih, S. dan Purwati, H. 2017. Analisis ketersediaan jagung nasional menuju pencapaian swasembada dengan pendekatan model dinamik. Jurnal Informatika Pertanian 26 (1): 41-48.

Pirngadi, K., Permadi, K. dan Toha, H.M. 2005. Pengaruh Pupuk Organik dan Anorganik Terhadap Hasil Padi Gogo Sistem Monokultur. Bogor, 12-14 Agustus 2005. Prosiding Optimasi Pemanfaatan Sumberdaya Pertanian Melalui Akselerasi Pemasyarakatan Inovasi Teknologi Mendukung Revitalisasi Pertanian, Pusat Analisis Sosial Ekonomi dan Kebijakan Pertanian, Bogor. 
Jurnal Tanah dan Sumberdaya Lahan Vol 7 No 1 : 93-100, 2020

e-ISSN:2549-9793, doi: 10.21776/ub.jts1.2020.007.1.12

Siregar A. F dan W. Hartatik. 2010. Aplikasi Pupuk Organik Dalam Meningkatkan Efisiensi Pupuk Anorganik pada Lahan Sawah. Diakses di http:/ / balittanah.lit-

bang.pertanian.go.id/ind/dokumentasi/prosidin gsemnas $2010 /$ adha $\% 20$ siregar.pdf pada 31 Agustus 2019.

Suharto, T.R.O., Setiawati, T.C. dan Winarso, S. 2018. Peningkatan ketersediaan dan serapan P pada tanaman jagung di lahan tercemar limbah padat lumpur (lime mud) melalui penambahan bahan organik. Jurnal Agroekoteknologi Universitas Andalas 2 (2): 1-26.
Sulaeman, Y., Maswar dan Effendi, D. 2017. Pengaruh kombinasi pupuk organik dan anorganik terhadap sifat kimia tanah dan hasil tanaman jagung di lahan kering masam. Jurnal Pengkajian dan Pengembangan Teknologi Pertanian 1 (20):1-12.

Yasin, M., Suarni, S., Santoso, B., Fascal, A., Talanca, H. dan M. J. Mejaya, M.J. 2017. Stabilitas hasil jagung pulut varietas bersari bebas pada dataran rendah tropis. Jurnal Penelitian Tanaman Pangan 3 (1): 223-232. 